\title{
INTEGRATED PARTICIPATIVE INSTRUCTIONAL SUPERVISION PLANNING AT PUBLIC JUNIOR HIGH SCHOOLS: A MULTISITE CASE STUDY AT THREE MIDDLE SCHOOLS IN BLITAR, EAST JAVA
}

\author{
Supriyono \\ Balitar Islamic University, Jl Majapahit no 4 Blitar, East Java, Indonesia \\ yonsupriyono@gamil.com; supriyono@unisbablitar.ac.id
}

\begin{abstract}
This research was aimed at revealing the integrated participative instructional supervision planning carried out at three public middle schools in Blitar, East Java. This study followed qualitative approach by using multisite case study design. This study was held in three different public middle schools in Blitar, East Java. Data was collected by using Observation, Interview, and Documentation. To ensure the data validity and reliability, assessments on credibility, dependability, conformability, and transferability were employed. Subjects were chosen by purposive sampling with snow balling technique involving district supervisors, principals, and senior teachers. Data was analyzed using interactive and modified induction methods. This research concluded that The integrated participative instructional supervision resulted the enhancement of teachers' performance and students learning outcomes as well as to the attainment of the department of education and culture and schools' visions and mission. It is suggested to be further researched using research and development approach.
\end{abstract}

Key words: Instructional supervision, planning, public junior high school

\section{INTRODUCTION}

Instructional supervision has been one of the important professional development supports for teachers. In Indonesia instructional supervision has been acknowledged as academic supervision which focuses on the supervision towards the instructional preparation, implementation, and evaluation as well as its follow up. The other form of supervision is managerial supervision. Academic supervision which is eventually the instructional supervision is held to enhance teachers' professionalism, to develop supervisory quality, and to build motivation (Manggar and Cahyono, 2013:7). Conceptually, Glickman, Gordon, and Ross-Gordon (2007) stated that instructional supervision is aimed at helping teachers develop their ability to manage learning process to achieve instructional objectives. Managerial supervision is concerned with administration and management of schools. Instructional supervision is a very important strategy of teachers' professionalism (Zepeda, 2007:2) and a way of teachers empowerment and continuous development (Suhardan, 2010:84). A recent study on the Instructional Supervision at middle schools conducted by Supriyono (2016) revealed interesting results on the process and program of supervision planning, organization, implementation, and evaluation. The final results on the focus of planning revealed that:

In the initial stage, the instructional planning involved educational leaders comprising head of the education department, official supervisors, and principals allowing participative program planning, synchronization, and shared decision. These caused better team work and synchronized objectives and targets. In the developing instructional and semester program, principals conducted program planning involving vice principals, senior teachers, and master teachers allowing contribution and suggestions for effective planning and arousing shared decision. The official supervisors visited principals to synchronize their programs. These 
cause effective programs with rational and factual objectives and targets expectations (Supriyono, 2016:218).

The study was a part of the dissertation research conducted within the year of 2012 to 2016 (Supriyono, 2017) which involved head of the education department, official supervisors, principals, vice principals, and senior teachers who have already been changed in 2017. Considering the importance and interesting results of the study, this research was done by the interest of further revealing such instructional supervision planning focusing on the process and program with different key players at the same education department and culture and schools. This can be noted as replication study using the same schools with different key players and key informant, except the teachers to ensure whether this research revealed the same results and further contributive results to instructional supervision. The replication is focused and deepened in the instructional supervision planning. Research replication has been a usual practice in research as stated by Bonett (2012:411) as follows:

Replication-extension studies combine results from prior studies with results from a new study specifically designed to replicate and extend the results of the prior studies. Replication-extension studies have many advantages over the traditional single-study designs used in psychology: Formal assessments of replication can be obtained, effect sizes can be estimated with greater precision and generalizability, misleading findings from prior studies can be exposed, and moderator effects can be assessed.

Using such consideration, this research was done by the intention of revealing the instructional supervision planning phenomena at the same schools with different key players to find out whether the previous results remain exist or further contributive results were available in order to consistently obtain the so-called integrated participative instructional supervision planning model.

\section{FOCUSES OF THIS RESEARCH}

Based on the explanation of the background of this research, the focuses of this research were formulated as follows:

a. How was the process of integrated participative instructional supervision planned and what phenomenological meanings were revealed?

b. How was the instructional supervision programmed and what phenomenological meanings were revealed?

\section{OBJECTIVES OF THIS RESEARCH}

Considering the focuses of this research, this research was aimed at

a. Describing the process of integrated participative instructional supervision planning and its phenomenological meanings,

b. Describing the programs of integrated participative instructional supervision and its phenomenological meanings.

\section{THEORETICAL REVIEW}

Instructional supervision has been mainly defined as the activities to provide professional assistance to develop teachers to improve their learning and teaching process for the success of students (Glickman, 1992), to influence 
teaching and learning as the opportunity for teachers to develop their capacity in contributing to the success of students (Sergiovanni and Starratt, 2002), to develop their professional capacities (Mantja, 2010, Burhanudin, 2007, Imron, 2007, Lekipiow, 2009, Teriningsi, 2009), and to help teachers to develop their abilities in managing instructional process to attain the instructional objectives (Direktorat Tenaga Kependidikan, 2007).

Historically, instructional supervision has been developed greatly. Within 800-1400 there was close supervision on religious and moral development focusing in the supervision of moral and religious development in England (Gwyn, 1961:4). This was also followed in New England within 1636-1647 which was done in New England or America (Gwyn, 1961:4). In 1827, in order to ensure that the instructional implementation at schools were suited the local school district guidance, the visiting committee supervision was implemented (Gwyn, 19615). Focusing on the instructional implementation in classes which cover the subject matters instruction to ensure that the implementation fulfilled the educational supervision, general supervision and special supervision were introduced in 1827 (Gwyn, 1961:5), which were also called as administrative inspection (Lucio and Mc. Nail, 1979:11).

Within 1900-1920 there appeared supervisions by specialists (Lucio and Mc.Neil, 1979:11). Within these years, Supervision to lead and help teachers (Cubberly, 1916, in Gwyn,1961:10) and Supervision for Improvement of Instruction to appraish teachers (Wagner, 1921 and Gwyn, 1961:10) were introduced. In 1922 there appeared the Supervision for Improvement of teaching act (Burton, 1922, in Gwyn, 1961:10). Further in 1924 instructional supervision was focused to help teaching and learning coordination, which was called Supervision for Stimulation of Instruction (Scott, 1924, in Gwyn, 1961:10). Instructional supervision using the scientific method was introduced in 1920-1960 as Scientific Supervision (Gwyn, 1961:11-13). In this era supervision was planned, organized, implementated, and evaluated on the basis of scientific method.

In 1930-1960 at the relatively same times, there appeared Supervision as Democratic Educational Leadership, Supervision as Guidance, Supervision as Curriculum Improvement, and Creative Supervision. The first was aimed at improving the teaching and learning process by using democratic methods; the second was aimed at giving guidance to teachers and students; and the third was aimed at improving teaching and learning process by focusing on the relevance to the curriculum, and the last was aimed at improving teaching and learning process creatively (Gwyn, 1961:11). Within 1940-1960 and 1956-1960 there were two kinds of instructional supervision introduces which were Supervision as Group Process and Supervision as Indigenous to Instructional Team. The first was aimed at enhancing social relationship or interpersonal relationship of teachers involving 
group instructional planning and the second was aimed at developing instructional supervision using internal supervisors (Gwyn, 1961:11).

In 1960s to 1970, there were two kinds of supervision introduced, which were clinical supervision and Supervision as Management. The first was aimed at improving teaching and learning process by using pre observation Conference, Observation, and Post observation Conferences (Cognan, 1973; Goldhammer, 1969; Goldhammer, Anderson and Krajeski, 1993; Glickman, Gordon, and RossGordon, 2007) and the second was aimed at doing inspection to education management which was administrative (Wiles and Bondi, 1986:7, Mantja, 2000). In the 1980s there were appeared Supervision as Instructional Management (Wiles and Bondi, 1986:7), Self Directed Supervision (Glattorn, 1984), Skills-Focused Supervision (Hunter, 1984), Social Work Supervision (Kandusin, 1985), Developmental Supervision (Glickman, 1985), Cognitive Based Supervision (Costa and Carmston, 1985, Garman, 1986), Peer Supervision or Collegial Supervision (Glattorn, 1987), Contingency Supervision (Hersey and Blanchard, 1988). These supervisory approaches had the similarities of aimed with different focuses and approaches off which the main aimes were to improve teaching and learning process for the benefit of teachers development and students success.

In 1990s, there were appeared several instructional supervision such as Differentiated Supervision focusing on improving teaching and learning process using differentiation(Glattorn, 1990), Organizational Supervision focusing on improving education using administrative and organizational approach (Sergiovanni, 1991), and Clinical Social Work aiming at ensuring teaching and learning process was done effectively by using interactive approach (Munson, 1993). In 2004 SuperVision as Developmental was introduced. This was a very comprehensive approach of supervision empowering principals and teachers for the benefit of the teachers development, students' success, and schools success (Glickman, Gordon, and Ross-Gordon, 2009).

In 2017, Integrated Participative Team Based Instructional Supervision which was aimed at improving teaching and learning proccess for the benefit of teachers development, students success and school success involving head of the Education Department, Principals, Vice Principals, Senior teachers, and Teachers were founded (Supriyono, 2016, 2017).

The latter provided references on the instructional supervision planning integratedly synchronizing the Education Department of education objectives, Schools Objectives, and Instructional Objectives and employing team based planning involving Head of the education Department, Official Supervisors, and Principals at the levels of Department and involving Official supervisors, Principals, Vice Principals, and Senior Teachers at the level of Schools. 


\section{RESEARCH METHOD}

This research was employing qualitative research using multisite case study design (Bogdan and Biklen, 1992). The qualitatif research was not quantifying data, but was meaningful on the basis of the natural setting or phenomenon (Bogdan and Biklen, 1982, Marshall and Rosman, 1995) and the researcher was the main instrument. The analysis was employing the Interactive Model of analysis (Miles and Hubberman, 1992) and Analytic Modified Induction of Theory Development (Bogdan and Biklen). The research framework was customized by using the reference of Arifin (1998). The analysis was done interactively during the process of data collection by doing data collection, data display, data reduction, data verification, and conclusion (Miles and Hubberman, 1992). Interactive analysis was done in the last three processes.

Observation, interview, and documentation using field notes, recording, interview schedule, and documents were used to collect the data. The observation consisted of descriptive, selective, and focused observation at the three sites. The interview consisted of in-depth interview with probing techniques. The information collected by using these techniques was transferred into the contact summary to enable the researcher for clear analysis. The contexts of this research were three public middle schools in Blitar, East Java, Indonesia. These three schools had different characteristics, but had similar cases on the instructional supervision.

To take the samples, purposive sampling was used by determining the key informant and to further take other samples, this research used snow balling techniques. The informant consisted of Head of the Education Department and Culture, three official supervisors, as well as three principals, three vice principals, six senior teachers, six teachers, and six students. To ensure the validity and reliability of the data, checking the credibility, dependability, conformability, and transferability with data triangulation both triangulation of sources and techniques, member check, collegial discussion, and audit involving scholars including Dr. Sasongko, Dr. Asmoni, and Dr Soim were done.

The analytic modified induction method of theory development was done by developing instructional supervision especially the instructional supervision plan as the bases of analysis, determining the sites and developing the research protocols, conducting research at the first site to find out temporary findings, conducting research at the second site to find out temporary findings, doing cross sites analysis of the temporary findings at the first and second sites to find out the temporary cross-sites finding, conducting research at the third site to find out the temporary findings, inducing the temporary findings of the cross site analysis between the first and second sites into the temporary findings at the third site by comparing both findings to obtain the similarity. Meanwhile, the differences were 
kept noted. From the final results of this research, the researchers formulate models and propositions of this research in terms of the substantive theory.

This research was conducted by the following phase: (1) preliminary study including reviewing previous research, developing the theoretical concepts, determining sites, and developing protocols, (2) field orientation, (3) focused explorative study including data collection and interactive analysis, (4) checking the four types of qualitative data validity and reliability, (5) conducting within sites and cross sites analysis, (6) formulating substantive model and theories, (7) making conclusions, (8) report writing, and (8) report finalization.

\section{FINDINGS}

The primary findings of this research can be explained as the followings: These were the ultimate primary findings after having final cross case analysis of the three sites. This research revealed two main categories of findings, which are process and program.

Firstly, in terms of the process the findings showed two obvious different interrelated facts. The first type of facts, as it was called Fact X, which included (1) Annual coordination meetings at the office of the department of education and culture involving the head of the department, official supervisors, and principals to discuss annual educational program planning including analyzing the current and previous situation as well as making shared decision on the ongoing teachers development and classroom process improvement through instructional supervision, (2) Official supervisors conducted provided professional development meeting of subject matter teachers to analyze previous year instructional supervision and ongoing teachers professional development, analyzing the results of annual coordination meetings, and formulating annual and semester educational program plan design, (3) Senior teachers conducted subject matters teachers workshop at the Department of Education and Culture office to evaluate their performance in the previous year, to discuss problem and solution, and to contribute feedback for instructional supervision planning, (4) *Senior teachers conducted workshops and professional meetings with teachers at schools to share problem and solution for references to be submitted to Principals as inputs for school program plan (5) Principals, Vice Principals, and Senior teachers formulated annual and semester instructional supervision planning coached by the official supervisors, (6) The Principals accompanied by the Vice Principals and Senior teachers conducted socialization of the annual and semester instructional program planning to teachers and staffs. Teachers and staffs were given opportunity to suggest their ideas and feedback, and (7) The principals finalized the instructional program plan and provided feedback to the Head of Education and Culture Department as advised by teachers and staffs. 
The second type of fact, which was the Y facts, were (1) the attainment of the same directions among the Head of Education and Culture, the Official supervisors, and the Principals, (2) the establishment of integrated participative instructional plan, (3) the attainment of teachers needs, (4) the synchronization of the official supervisors and principal instructional program plan, (5) the opportunities for teachers to submit ideas, (6) the attainment of Schools and Department of Education and Culture vision, mission, and objectives, and (7)the establishment of ongoing teachers professional activities.

These facts were similarities of findings among the three schools. There were differences noted at the $X$ fact number 4 . Therefore, this was marked by asterisk note. In the first sites, senior teachers conducted the workshop and academic meetings at schools in the so-called Musyawarah Guru Mata Pelajaran (Subject Matter Teachers Association) Discussion Program. In the second sites, while the senior teachers conducted the same meetings with that off the first sites, the senior teachers also conducted the lesson study program. In the third site, senior teachers did not do the same kinds of workshop and official meeting as the first and the second sites, but they conducted workshop and meeting to all teachers in groups at school.

Secondly, in terms of the programs, this research revealed that these three schools had the same programs, which were (1) Annual and semester instructional supervision programs formulated with consideration of the results of official meetings on the process stage and results of previous year instructional supervision report, report of previous year instructional supervision analysis, and the previous year on going teachers professional development plan, (2) Instructional supervision focused guide which include professional assistance in teaching and learning preparation, teaching and learning implementation, teaching and learning evaluation, (3) teachers ability appraisal program in preparing the teaching and learning program, conducting teaching and learning process, and evaluating teaching and learning results, (4) ongoing teachers professional development in communication information technology, action research, and scientific writing, and (5) Ongoing teachers professional development support program by the official supervisors, principals, senior teachers, and collegial tutors. These (X) facts were followed by the second facts (Y) as follows: (1) the proper target of the ongoing teachers professional development, (2) the enhancement of teachers performance, (3) the enhancement of teachers professional competence, and (4) the enhancement of students learning outcomes.

These findings showed that the instructional supervision plan was conducted integratedly combining the supports for teachers to improve their teaching and learning program for the attainment of students success and ongoing professional development as well as participatively involving the head of the Department of Education and Culture, Senior supervisors, Principals, Vice 
Principals, and Senior Teachers. It likely showed acts of team work. From these findings, the researcher formulated model and found meanings in the form of propositions. The main findings could be described into a model of Integrated Participative Instructional Supervision Planning as follows:

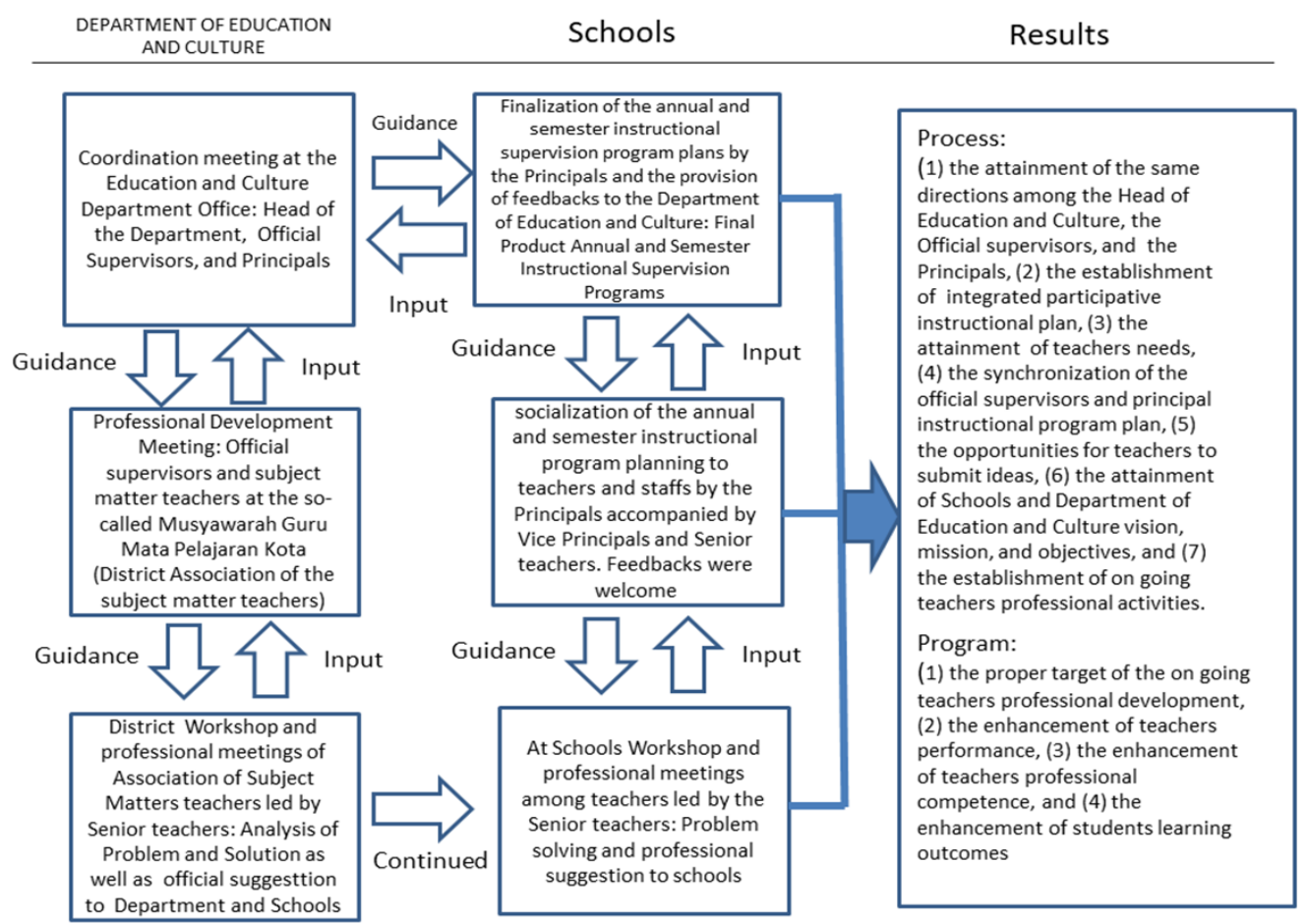

Figure 1: Model of Integrated Participative Instructional Supervision Planning

Ultimately this research revealed the following propositions:

a. Proposition number 1: The integrated participative instructional supervision plan process involving the Head of the Education Department and Culture, Official Supervisors, Principals, Vice Principals, Senior teachers, and teachers resulted (1) the attainment of the same directions among the Head of Education and Culture, the Official supervisors, and the Principals, (2) the establishment of integrated participative instructional plan, (3) the attainment of teachers needs, (4) the synchronization of the official supervisors and principal instructional program plan, (5) the opportunities for teachers to submit ideas, (6) the attainment of Schools and Department of Education and Culture vision, mission, and objectives, and (7) the establishment of ongoing teachers professional activities.

b. Proposition number 2: The annual and semester programs formulated through the integrated participative instructional supervision resulted (1) the proper target of the ongoing teachers professional development, (2) the enhancement of teachers performance, (3) the enhancement of teachers professional competence, and (4) the enhancement of students learning outcomes 


\section{DISCUSSION}

Results of this research showed the participation and involvement of all key educational players including teachers in which teachers were empowered to actively develop their professional competence in teaching and learning for the benefit of the students success. Both individual and group activities were activated. Such kind of supervisory actions supported the notion of Supervision as Group Processes (Gwyn, 1961:11-15). In such activities the supervision also involved and empowered the senior teacher, which can be called as master teacher. Such kind of supervision was in line with the so-called Supervision as Indigeneous to Instructional Team (Gwyn, 1961:11). Eventhough democratic situation was also obvious, there was not obviously the practices of inspection, instead it was more on collegial and clinical processes. Therefore, result of this research did not exactly provide similarity with the Supervision as Democratic Educational Leadership (Gwyn, 1961:11-13), which functioned as Supervision as Inspection. Since the notions of the on going teachers development and clinical approach turned out to be major of the supervisory practices, result of this research supported the theory of Developmental Supervision (Glickman, 1985) and Collegial Supervision (Gwyn, 1961).

Results of this research also found the notions of Supervision as Management (Wiles and Bondi, 1986:7), Supervision as Instuctional Management (Wiles and Bondi, 1986:7), and Supervision as Developmental (Glickman, Gordon, and Ross-Gordon, 2009). Within the clinical supervisory practices, instructional improvement and supervisory professional assistance were so obvious that such practices were compatible with the notions of Supervision to lead and help teachers (Cubberly, 1916) as well as Supervision for Improvement of Instruction (Wagner, 1921). The school leaders meetings by discussing the instructional supervision for improvement of teaching, learning, outcomes, and schools achievement showed the compatibality to the practice of Supervision for Improvement of Teaching Act (Gwyn, 1961:11-13), Supervision as Curriculum Improvement (Gwyn, 1961:11-16), and Developmental Supervision (Glickman, 1985).

Results of this research as a result of the replicative process showed that the supervision planning practices strenghtened results of the previous research (Supriyono, 2016, 2017) and made more powerful in teachers' development for not only concencerned with action research and information communication technology, but also in scientific writing.

\section{CONCLUSION AND SUGGESTION}

This research concluded that the Integrated Participative Instructional Supervision correlated with the improvement of teachers competence in teaching and learning, the improvement of team work, the improvement of students 
performance, the attainment of district and schools' objectives, and powerful teachers professional development of theor competences in teaching and learning, action reearch, information communication technology, and scientific writing.

Upon reflecting the results of this research, the researcher sugested that the Integrated Participative Instructional Supervision Model is implemented in the instructional supervision practices at schools widely. It was alaso suggested that the model would be researched with Research and Development method.

\section{REFERENCES}

Arifin, I. 1998. Kepemimpinan Kepala Sekolah dalam Mengelola Madrasah \ Ibtidaiyah dan Sekolah Dasar Berprestasi: Studi Multi Kasus pada MIN 1 Malang, MI Mamba'ul Ulum, dan SDN Ngaglik 1 Batu di Malang.Disertasi.Malang:PPS IKIP Malang

Burhanudin. 2007. Supervisi Dalam Rangka Pembinaan Profesional. Dalam Burhanudin, Sutopo, H., Imron, A., Maisyaroh, Ulfatin, N (Eds).2007. Supervisi Pendidikan dan Pengajaran: Konsep, Pendekatan, dan Penerapan Profesional. Malang: FKIP Universitas Negeri Malang.

Bogdan, R.C. and Biklen, S.K. 1982. Qualitative Research For Education: An

Introduction to Theory and Method.London: Allyn and Bacon, Inc

Bonnet, D.G. 2012. Replication-Extension Studies.Current Direction in

Psychological Science, 21(6) 409-412, DOI: $10.1177 / 0963721412459512$

http://cdps.sagepub.com

Burton, W.H. 1922. Supervision and The Improvement of Teaching. New York:

D. Ampleton and Company

Cognan, M.L. 1973. Clinical Supervision. Boston: Houghton Miflin

Costa, A and Gramston, R. 1985.Supervision for Inteligent teaching, Educational Leadership 42 (5)

Direktorat Tenaga Kependidikanl. 2007.Pendidikan dan Latihan Supervisi

Akademik Dalam Peningkatan Profesionalisme Guru. Jakarta: Kementrian Pendidikan Nasional

Garman, N.B. 1986 Reflection, The Heart of Clinical Supervision Amodersn

Rationale for Professional Practice. Journal for Curriculum and

Supervision.Fall 1986. Vol. 2, No 1.1-24

Glattorn, A.A. 1984. Curriculum Renewal. Alexandria, VA: Association for Supervision and Curriculum Development

Glattorn, A.A. 1990. Differentiated Supervision. Alexandria, VA: Association for Supervision and Curriculum Development

Glickman, C.D. 1985. Development as the Aim of Instructioal Supervision.

Athens: University of Georgia,

Glickman, C.D. 1992. Supervision in Transition. Alexandria, VA: ASCD

Glickman,C.D., Gordon, S.P., and Ross-Gordon, J.M. 2007. Supervision and 
JARES, Vol. 3 No. 1 March, 2018; p-ISSN: 2502-826X; e-ISSN: 2503-1163

Copyrights@ Balitar Islamic University, Blitar, Indonesia;

Http://jares.unisbablitar.web.id

Instructional Leadership:Adevelopmental Approach.7th Ed. Boston:

Pearson

Glickman,C.D., Gordon, S.P., and Ross-Gordon, J.M. 2009. The Basic Guide to

Supervision and Instructional Leadership: A developmental Approach.2nd

Ed. Boston: Allyn and Bacon

Goldhammer, R. 1969. Clinical Supervision Special Methods for The Supervision

of Teachers.New York: Hold, Rinehart, and Winston

Goldhammer, R., Anderson, R.H., \& Krajewski, R.J. 1993. Clinical supervision:

Special methods for the supervision of teachers. (3rd ed.). Forth Worth:

Harcourt Brace Jovanovich College Publishers.

Gwyn, J.M. 1961. Theory and Practice of Supervision. Toronto: Dodd, Meal, \&

Company

Hersey, P and Blachard, K. 1988.Management of Organization Behaviorutilizing

Human Resources (5th Ed). Englewood Cliffs, N.J.: Prentice-Hall, Inc

Hunter, M. 1984. Knowing, teaching, and supervising. In P. Hosford (Ed.), Using

what we know about teaching (pp. 169-192). Alexandria, VA: Association

for Supervision and Curriculum Development.

Imron, A. 2007. Pendekatan Ilmiah Supervisi. Dalam Burhanudin, Hendyat

Sutopo, Ali Imron, Maisyaroh, dan Nurul Ulfatin. 2007. Supervisi

Pendidikan dan Pengajaran: Konsep, Pendekatan dan Penerapan

Profesional. Malang: Fakultas Ilmu Pendidikan, Universitas Negeri

Malang

Kandusin, A. 1985.Supervision in Social Work. 2nd Ed. Newyork: Columbia University Press

Lekipiow, A. 2009. Hubungan Pelaksanaan Supervisi Pengajaran, Ketrampilan

Manajerial Kepala Sekolah dan Kompensasi Kerja dengan Kinerja Guru

SMP Negeri di Kota Ambon. Disertasi. Malang: Program Pasca Sarjana,

Universitas Negeri Malang.

Lucio, W.H. and McNeil, J.D.1979. Supervision in Thought and Action. New

York: McGraw-Hill Book Co

Manggar, Y and Cahyono,Y. 2013. Supervisi Akademik. Depok:LPPKS

Mantja, W. 2000. Bahan Ajar Model Pembinaan Profesional Guru Berwawasan

Pengembangan Sumber Daya Manusia: Suatu Kajian Konseptual-Historik

dan Empirik. Pidato Pengukuhan Guru Besar IKIP Malang.Malang: IKIP

Malang

Mantja, W.2010.Profesionalisasi Tenaga Kependidikan: Manajemen Pendidikan

dan Supervisi Pengajaran. Kumpulan Karya Tulis Terpublikasi.Malang:

Penerbit Elang Emas

Marshall, C., \& Rossman, G. B. 1995. Designing qualitative research. 2nd Ed

Thousand Oaks, CA: SAGE PublicationsMiles, M.B. and Hubberman,

A.M.1992. Qualitative Data Analysis.Beverly Hill, CA: Sage Publication, Inc 
Munson, C. 1993. Clinical Social Work Supervision. Second Ed. New York: Howorth Press

Sergiovanni, T.J.1991. The Principalship: A Reflective Practice Perspective. Boston: Allyn \& Bacon

Scott, C.E. 1924. Educational Supervision. Milwaukee:The Bruce Publishing Company

Sergiovanni, T.J. and Starrat, R.J. 2002. Supervision: A Redefinition. Boston, MA: Mc Graw-Hill

Suhardan,D.H. 2010. Supervisi Profesional: Layanan dalam Meningkatkan Mutu Pembelajaran di Era Otonomi Daerah. Bandung:Alfabeta

Supriyono. 2016. Integrated Participative Team Based Instructional Supervision Management At MiddleSchools in Blitar,East Java Indonesia:Amultisite Case Study. Journal of Social Sciences (COES \& RJ-JSS), ISSN (E): 2305, ISSN (P): 2305-9494,Volume 5,Number 3,July 2016, www.centreofexcellence.net https://doi.org/10.25255/jss.2016.5.3.212.228

Supriyono. 2017. Supervisi Pembelajaran di Sekolah Menengah Pertama (Studi Multi Situs Pada SMPN 1, SMPN 2, dan SMPN 4 Kota

Blitar).Disertasi.Malang: Universitas Negeri Malang

Terminingsi, A. 2009. Hubungan Supervisi Pengajaran, Motivasi kerja, Kinerja Guru dengan Prestasi Belajar Siswa SD Negeri di kabupaten Baru.

Disertasi. Malang: Program Pasca Sarjana, Universitas Negeri Malang.

Wagner, C.A. 1921. Common Sense in School Supervision. Melwaukee: Bruce Publishing Company

Wiles, J. And Bondi, J. 1986. Supervision: A Guide to Practice. Second Ed. Ohio: A Bell and Howell Company.

Zepeda.2007.Instructional Supervision: Applying Tools and Concepts.2nd Edition.Larchmont,NY:Eyeon Education,Inc 